\title{
A HYBRID MADM ANALYSIS IN EVALUATING PROCESS OF CHEMICAL WASTEWATER PURIFICATION REGARDING TO ADVANCE OXIDATION PROCESSES
}

\author{
Mohamad Reza KHODADADI ${ }^{a}$, Sarfaraz HASHEMKHANI ZOLFANI ${ }^{\text {, }}$, Morteza YAZDANI ${ }^{c}$, \\ Edmundas Kazimieras ZAVADSKAS ${ }^{\mathrm{d}}$ \\ ${ }^{a}$ Department of Nanotechnology, Semnan University, P.O Box 19111-35131, Semnan, Iran \\ ${ }^{b}$ Department of Management, Science and Technology, Technology Foresight Group, \\ Amirkabir University of Technology (Tehran Polytechnic), P.O. Box 1585-4413, Tehran, Iran

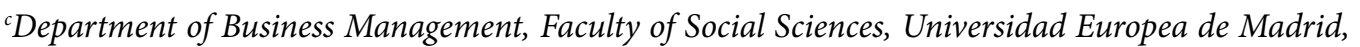 \\ 28670 Madrid, Spain \\ ${ }^{d}$ Research Institute of Smart Building Technologies, Vilnius Gediminas Technical University, \\ Sauletekio al. 11, LT-10223 Vilnius, Lithuania
}

Submitted 14 Sep. 2016; accepted 09 Jan 2017

\begin{abstract}
Organic components, widely spread in water by industrial sources become emerging Contaminants in the water. Due deficient removal in conventional wastewater treatments, advanced treatment should be considered for industrial wastewaters removing. Advance oxidation processes (AOPs) can be used as an effective subset of chemical treatment for degradation of toxic from water in industrial processing plant. Two Multiple Criteria Decision Making (MCDM) methods based on hybrid SWARA-WASPAS are organized to investigate efficiency of different sort of AOPs: ozonation, fenton, electrochemical Oxidation, UV/Photo-catalysis, $\mathrm{UV} / \mathrm{H}_{2} \mathrm{O}_{2}$. Based on MCDM, Fenton is the most possible AOPs for application in wastewater treatment areas. In this study, SWARA is deployed in evaluating criteria that were identified in literature review, and WASPAS is used for evaluating and ranking the methods. The main point of this study is based on real data.
\end{abstract}

Keywords: wastewater, wastewater purification, AOPs, MCDM, SWARA, WASPAS.

\section{Introduction}

Population growth and industrialization caused more pollution of hydrosphere with organic and inorganic compounds (Oppenländer 2003). Sanitation is one of the essential practices in developing infrastructures in each government while encompasses wastewater treatment in each region of a country to fight for pollution and control it. Regarding recent UNICEF reports of 780 million people without access to safe drinking water, improvement in sanitation and purification methods needs critical attention. In fact purification is done to remove chemicals, biological and physical contaminants. Water purification is a process to reuse and recycle wastewaters for a specific purpose such as industrial usage.

In the literature four main sources of wastewaters are (1) domestic sewage, (2) industrial wastewaters, (3) agricultural runoff and (4) storm water and urban runoff. Although agricultural and urban runoff wastewaters have less importance, however domestic and industrial wastewater treatments are becoming increasingly critical due to rapid growth of industrialization and mechanization. Therefore all of the chemical compounds, materials and energy which are discharged into the water can potentially influence hydrosphere, global health and environment. This discharge can finally lead to transaction of energies and materials within an ecosystem's hydrology and can be a strong source of pollutant (contaminant). Role of AOPs as an effective chemical treatment is to degrade toxics and minimize the pollutants from the water that is investigated in this section. Almost all of the industries as cosmetics, wood and food and textile industries which contain chemical nature and processes can potentially produce water pollution.

Corresponding author: Sarfaraz Hashemkhani Zolfani

E-mail: sa.hashemkhani@gmail.com 
Different treatment technologies are used to remove contaminants as environmental disinfectants and wastewater purification methods like chemical, physical, and biological operations. Wastewater purification is a complex process that needs to combine physical-chemical methods. Particularly, elimination of organic contaminations such as phenols, solvents, dye, etc., from wastewater is hard. Physical and mechanical treatment including filtration and membrane technique leads to secondary wastewater and higher cost. None of these treatment methods is effective enough to produce water with acceptable levels of organic compounds (Leyva-Díaz et al. 2015). Also, organic substances are stable compounds to be decomposed by common biological treatment. Literatures show that biological methods employed for degradation of organic compounds are ineffective and combined chemical- biological methods are suggested (Mantzavinos, Psillakis 2004). For instance, the biological treatments cannot be effective to remove most of complex poly-aromatic dye in textile industry. Chemical processes cannot be neglected and are highly recommended in decision making. Chemical treatment of wastewater may also be applied where there is limited access to the biological treatment.

Recent developments in the domain of chemical water treatment have led to an improvement in oxidative degradation procedures to remove organic materials in wastewater by oxidation through catalytic and photochemical methods. They are generally referred to advanced oxidation processes (AOPs) which has a strong impact on simple sanitation infrastructure decision and economical feasible approach. AOPs as chemical processes are promising methods to treat the most organic compounds from polluted water (Sievers 2011). It is a powerful tool for degradation and mineralization of pollutants in water and wastewater treatment, including hydrogen peroxide, ozone or special catalysts such as titanium dioxide. The use of a strong oxidizing agent can result in a high degree of wastewater treatment, including the breakdown of chemical recalcitrant and toxic compounds.

The aim of the present paper is to investigate the efficiency of different AOPs in wastewater treatment plant for wastewater management, namely Ozonation, Fenton, electrochemical Oxidation, UV/Photo-catalysis, UV/ $\mathrm{H}_{2} \mathrm{O}_{2}$, and various integrated processes, regarding (i) efficiency and capacity of each technology for mineralization organic materials loads, (ii) comparable low cost and high cost technologies related economic and operational feasibility (iii) important chemical indicators to rank the possibility of techniques for removing effluents' toxicity. In this way, policy and decision making processes related to these issues are complicated. Multiple Criteria Decision Making (MCDM) (Liu et al. 2016; Liu, Shi 2015; Khan, Samadder 2015; Liu, Jin 2012; Turskis et al. 2012; Kucas 2010) frameworks can be a good choice for making an appropriate decision. Significance and contribution of multi criteria decision tools was applied in wide range of real life applications (Liu et al. 2011, 2012). Two MCDM methods are deployed in this study for making sound decisions. At first, SWARA is deployed for evaluating and weighting the criteria of this research. Must important criteria are identified from literature review. At next step, WASPAS method is deployed for evaluating different considerable alternatives of AOPs.

\section{Literature review}

In the literature review section, the significance of AOPs and its important parameters which have direct effect on term of AOPs wastewater treatment are discussed in Table 1. Several researches have reported applying different sort of AOPs and comparing them with conventional chemical methods. The high efficiency of AOPs in degradation of chemical toxin and pollution from water has been mentioned.

Sharma et al. (2012) compared advance and conventional oxidation processes for removing Microcystins (MCs) from water. It has been reported that AOPs are more effective and friendly to the environment than conventional chemical processes to convert a great variety of organic compounds into $\mathrm{CO}_{2}$ and mineral acids. Study showed rate of pollution degradation with AOPs is faster than chlorine and chlorine dioxide as conventional methods.

Ozonation technology as initial AOPs has been scrutinized. Gómez-Pacheco et al. (2011) evaluated Ozonation process and showed a reasonable decrease in total organic carbon (TOC) performance with degradation of tetracyclines (TCs) from water. The result showed a rapid mineralization of organic compound and direct relation between operation variables and pollution degradation.

Several parameters are included to investigate different sort of AOPs, which make it hard to approach a prospective strategic decision making. Canizares et al. (2009a) compared three different AOPs such as: ozonation, electrochemical oxidation and Fenton. They illustrated that the efficiencies of these three technologies were critically depended on concentration of pollutant. Also, the operation cost analysis showed Fenton oxidation process had lower expenses than two others methods. In contrast, the cost calculation for two important oxidation processes, ozonation and Fenton reaction in a laboratory and pilot scale have been presented. This investigation showed Fenton reagent treatment was more expensive when compared to ozonation that is due to additional chemical cost for adjusting $\mathrm{pH}$ value of Fenton process (Krichevskaya et al. 2011).

Chang et al. (2008) took into account chemical and economic indicators for ozonation experiment. They investigated pollution and organic carbon removing were $\mathrm{pH}$ - dependent and the results showed the ozonation 
could not remove the pollutants entirely. The results declare a short ozone contact time has a better cost savings. Also, Fenton process has been under total cost and mineralization processes analyzes (Carra et al. 2013). They evaluated cost reduction has a direct correlation with the level of mineralization that higher mineralization levels cause significant decrease in financial terms.

Tizaoui et al. (2011) reported photo catalytic as an available AOPs technique for removing wastewater pollution by comparison with $\mathrm{UV} / \mathrm{H}_{2} \mathrm{O}_{2}$ and ozonation processes. The results of this study successfully showed photo catalytic process was the most effective way for degradation pollution from water. Also, several researches tried to analyze the efficiency of different catalysts such as $\mathrm{TiO}_{2}$ and $\mathrm{ZnO}$ for removing chemicals from water. They evaluated the optimum amount of catalyst, value of $\mathrm{pH}$ and the electrical energy cost as important indicators for reducing pollution from water (Lizama et al. 2002).

Exploring different advance oxidation processes (ozonation and its relatives, Fenton and photo catalysis) have been performed with ultra violet or solar source as energy consumption indicators (Esplugas et al. 2002). In addition, the research showed the ratio of photocatalysis process was five times lower than $\mathrm{UV} / \mathrm{H}_{2} \mathrm{O}_{2}$ while the ability of recycling of photocatalyst powder could decrease the total cost of this process.

Cabral da Silva et al. (2013) used electrochemical oxidation to produce fresh water. Through this method they analyzed different parameters such as $\mathrm{pH}$, total organic carbon (TOC) and energy consumption and mentioned electrochemical treatment method could be a feasible pretreatment process for the petrochemical industry. Also, Canizares et al. (2009a, 2009b) compared electrochemical oxidation method with other oxidation process. They believed electrolyte salt as a chemical parameter can improve efficiency and decrease total amount of pollution.

Autin et al. (2013) used an annular reactor to compare photocatalyst and hydrogen peroxide processes. It has been figured out that the optimization of reactor design, catalyst particle properties, and efficiency of UV lamp source will ultimately reduce the energy consumption. Moreover, different approaches presented dye pollution degradation using photocatalyst such as titanium dioxide $\left(\mathrm{TiO}_{2}\right)$. Some advances of this kind of oxidation have been performed for degradation of organic pollutants in wastewater (Teh, Mohamed 2011).

Chen et al. (2011) studied water pollution treatment for reusing water with $\mathrm{TiO}_{2}$ photocatalyst method. They evaluated various parameters such as light source and retention time and mentioned that the proposed system can decrease the operating and maintenance costs of wastewater treatment for agricultural and domestic use.

\section{The model of research}

Table 1 illustrates the references of parameters as the model of research that has been done for adjusting the environmental, economical and chemical evaluation which was reported by authors. Table 2 demonstrates all information

Table 1. The model of research

\begin{tabular}{|c|c|}
\hline Parameters & Reference \\
\hline Mineralization & $\begin{array}{l}\text { Lizama et al. 2002; Esplugas et al. 2002; Chang et al. 2008; Canizares et al. 2009a, 2009b; Tizaoui et al. } \\
\text { 2011; Gómez-Pacheco et al. 2011; Krichevskaya et al. 2011; Autin et al. 2013; Prieto-Rodriguez et al. } \\
\text { 2013; Carra et al. 2013; Cabral da Silva et al. } 2013\end{array}$ \\
\hline $\begin{array}{l}\text { Volume of wastewater } \\
\text { treated }\end{array}$ & $\begin{array}{l}\text { Lizama et al. 2002; Esplugas et al. 2002; Chang et al. 2008; Canizares et al. 2009a, 2009b; Tizaoui et al } \\
\text { 2011; Gómez-Pacheco et al. 2011; Krichevskaya et al. 2011; Autin et al. 2013; Prieto-Rodriguez et al. } \\
\text { 2013; Carra et al. 2013; Cabral da Silva et al. } 2013\end{array}$ \\
\hline Capital costs & Canizares et al. 2009b; Carra et al. 2013 \\
\hline Operating costs & $\begin{array}{l}\text { Canizares et al. 2009a; Krichevskaya et al. 2011; Carra et al. 2013; Prieto-Rodriguez et al. 2013; Cabral } \\
\text { da Silva et al. 2013: }\end{array}$ \\
\hline Energy consumption & $\begin{array}{l}\text { Lizama et al. 2002; Canizares et al. 2009b; Krichevskaya et al. 2011; Cabral da Silva et al. 2013; Autin } \\
\text { et al. } 2013\end{array}$ \\
\hline $\mathrm{pH}$ levels & $\begin{array}{l}\text { Lizama et al. 2002; Esplugas et al. 2002; Gómez-Pacheco et al. 2011; Chang et al. 2008; Canizares et al. } \\
\text { 2009a; Tizaoui et al. 2011; Krichevskaya et al. 2011; Autin et al. 2013; Prieto-Rodriguez et al. 2013; } \\
\text { Carra et al. 2013; Cabral da Silva et al. } 2013\end{array}$ \\
\hline $\begin{array}{l}\text { Total time for decreasing } \\
\text { pollution }\end{array}$ & $\begin{array}{l}\text { Lizama et al. 2002; Esplugas et al. 2002; Chang et al. 2008; Canizares et al. 2009a, 2009b; Tizaoui et al. } \\
\text { 2011; Gómez-Pacheco et al. 2011; Autin et al. 2013; Prieto-Rodriguez et al. 2013; Carra et al. 2013; } \\
\text { Krichevskaya et al. 2011; Cabral da Silva et al. 2013 }\end{array}$ \\
\hline $\begin{array}{l}\text { Amount of chemical } \\
\text { material used }\end{array}$ & $\begin{array}{l}\text { Lizama et al. 2002; Chang et al. 2008; Canizares et al. 2009a; Krichevskaya et al. 2011; Tizaoui et al. } \\
\text { 2011; Autin et al. 2013; Prieto-Rodriguez et al. } 2013\end{array}$ \\
\hline Pollution concentration & $\begin{array}{l}\text { Krichevskaya et al. 2011; Cabral da Silva et al. 2013; Prieto-Rodriguez et al. 2013; Carra et al. 2013; } \\
\text { Autin et al. } 2013\end{array}$ \\
\hline
\end{tabular}


about criteria and sub-criteria that are used in different aspects of decision making. These criteria are organized based on environmental, economic and chemical factors for five AOPs: Ozonation, Fenton, UV/Photo-catalysis, Electrochemical Oxidation and $\mathrm{UV} / \mathrm{H}_{2} \mathrm{O}_{2}$. Environmental factors represent the capacity of each technology for elimination of organic pollution and their capability for mineralization organic materials to mineral materials (Saeed, Sun 2012). Economic study is prepared to compare low cost and high cost technologies related the pollutant treatment. These indicators include capital costs, operating costs and energy consumption. Capital costs involve expenses incurred for fixed equipment, installation and organic matter mineralization for an industrial-scale plant. Operating costs consist of treatment plant and all machinery that are required to operate a process. Furthermore chemical process of waste water treatment is a process that consumes electrical energy. This can be an important factor to determine operation costs. The volumetric electrical energy consumption per order (EE/O) and the electrical energy consumption cost are determined according to rated power $(\mathrm{kW})$ of the AOPs system and radiation time (h) per volume $\left(\mathrm{m}^{3}\right)$ of waste water that is treated (Kim et al. 2012). The third section of Table 2 is related to important chemical indicators such as total time for decreasing pollution, $\mathrm{pH}$ levels, and average amount of chemi$\mathrm{cal}$ materials that were used for treatment. The amounts of pollutions were studied in their basic amount in each treatment method. In this study the importance of $\mathrm{pH}$ level that has to be adjusted for different AOPs treatment has been considered. The $\mathrm{pH}$ level is important factor that can cause an increase in amount of pollution. Finally, the data in each column for each treatment method have been calculated in average such as the years of practice with the information extracted from references as mentioned in the Table 2.

Water treatment based AOPs acts in a way to reduce costs and increase process efficiency. There are multiple data that are reported in different articles and build a challenging situation for selecting suitable parameters. In this way the best parameters have been found within various articles.

Table 2. Environmental, economical and chemical factors for five AOPs

\begin{tabular}{|c|c|c|c|c|c|c|c|c|}
\hline \multirow[b]{2}{*}{$\begin{array}{l}\text { Unit/ Para- } \\
\text { meters/Ref }\end{array}$} & & \multirow[b]{2}{*}{ The treatment method } & & Ozonation & Fenton & $\begin{array}{l}\text { Electro- } \\
\text { chemical } \\
\text { Oxidation }\end{array}$ & $\begin{array}{c}\text { UV } \\
\text { Photo- } \\
\text { catalysis }\end{array}$ & $\begin{array}{l}\mathrm{UV} \\
\mathrm{H}_{2} \mathrm{O}_{2}\end{array}$ \\
\hline & & & & $\begin{array}{l}\text { Gómez- } \\
\text { Pacheco et al. } \\
\text { 2011; Chang } \\
\text { et al. 2008; } \\
\text { Canizares et al. } \\
\text { 2009a; Tizaoui } \\
\text { et al. 2011; } \\
\text { Krichevskaya } \\
\text { et al. } 2011\end{array}$ & $\begin{array}{c}\text { Canizares } \\
\text { et al.2009; } \\
\text { Prieto- } \\
\text { Rodriguez et al. } \\
\text { 2013; Carra } \\
\text { et al. 2013; } \\
\text { Krichevskaya } \\
\text { et al. } 2011 \text {; } \\
\text { Canizares et al. } \\
2009\end{array}$ & $\begin{array}{l}\text { Canizares } \\
\text { et al. } \\
\text { 2009a; } \\
\text { Cabral da } \\
\text { Silva et al. } \\
\text { 2013; } \\
\text { Canizares } \\
\text { et al. } \\
\text { 2009b }\end{array}$ & $\begin{array}{c}\text { Tizaoui } \\
\text { et al. } 2011 ; \\
\text { Lizama et al. } \\
\text { 2002; Autin } \\
\text { et al. } 2013 \text {; } \\
\text { Prieto- } \\
\text { Rodriguez } \\
\text { et al. } 2013\end{array}$ & $\begin{array}{l}\text { Tizaoui } \\
\text { et al. } \\
2011 ; \\
\text { Autin } \\
\text { et al. } \\
2013 ; \\
\text { Esplugas } \\
\text { et al. } 2002\end{array}$ \\
\hline \multirow{2}{*}{$\begin{array}{l}\text { Environ- } \\
\text { mental }\left(\mathrm{C}_{1}\right)\end{array}$} & $\%$ & Mineralization $\left(\mathrm{C}_{1-1}\right)$ & Max & 52.85 & 64.25 & 88.90 & 85 & 87.50 \\
\hline & Litter & $\begin{array}{l}\text { Volume of wastewater } \\
\text { treated }\left(C_{1-2}\right)\end{array}$ & Max & 1.40 & 17.20 & 1.05 & 12.3 & 5.10 \\
\hline \multirow{3}{*}{$\begin{array}{l}\text { Economic } \\
\left(\mathrm{C}_{2}\right)\end{array}$} & $€ . \mathrm{m}^{-2}$ & Capital costs $\left(\mathrm{C}_{2-1}\right)$ & Min & 88639 & 8568.50 & 50210 & 70400 & 10800 \\
\hline & $€ . \mathrm{m}^{-3}$ & Operating costs $\left(\mathrm{C}_{2-2}\right)$ & Min & 546.59 & 6.20 & 12.19 & 27.30 & 50.50 \\
\hline & $\mathrm{KW} \mathrm{h} \mathrm{m} \mathrm{m}^{-3}$ & $\begin{array}{l}\text { Energy consumption } \\
\left(\mathrm{C}_{2-3}\right)\end{array}$ & Min & 2070 & 1 & 219.28 & 31.75 & 5.4 \\
\hline \multirow{4}{*}{$\begin{array}{l}\text { Chemical } \\
\left(\mathrm{C}_{3)}\right.\end{array}$} & - & $\mathrm{pH}$ levels $\left(\mathrm{C}_{3-1}\right)$ & - & 7 & 2.9 & 7.40 & 7.40 & 6.30 \\
\hline & $\min$ & $\begin{array}{l}\text { Total time for decrea- } \\
\text { sing pollution }\left(C_{3-2}\right)\end{array}$ & Min & 82.93 & 50 & 150 & 153.75 & 33.75 \\
\hline & $\mathrm{mg} / \mathrm{L}$ & $\begin{array}{l}\text { Amount of chemical } \\
\text { material used }\left(\mathrm{C}_{3-3}\right)\end{array}$ & Min & 54.41 & 1017.21 & 5025 & 434 & 696 \\
\hline & $\mathrm{Mol} / \mathrm{Lit}$ & $\begin{array}{l}\text { Pollution } \\
\text { concentration }\left(\mathrm{C}_{3-4}\right)\end{array}$ & $\operatorname{Max}$ & $1.23 \times 10^{-3}$ & $5.2 \times 10^{-4}$ & $4.79 \times 10^{-3}$ & $2.87 \times 10^{-3}$ & $5.67 \times 10^{-5}$ \\
\hline $\begin{array}{l}\text { Average Year } \\
\text { of practice } \\
\left(\mathrm{C}_{4}\right)\end{array}$ & Year & - & $\operatorname{Max}$ & 2010 & 2011 & 2010 & 2010 & 2009 \\
\hline
\end{tabular}




\section{Methodology}

The general framework of this research is organized based on MCDM concept. The methodology of this research is established based on two different MCDM methods as a hybrid method. SWARA and WASPAS have been used together first time in a research in 2013. Hashemkhani Zolfani et al. (2013a) applied this hybrid method in a research for decision making in the business issue. Moreover in this short period of time some other researches are organized based on this new hybrid methodology. All of other researches based on SWARA-WASPAS are listed below:

Vafaeipour et al. (2014) in assessment of regions priority for implementation of solar plants; Bitarafan et al. (2014) in evaluation of real-time intelligent sensors for structural health monitoring of bridges.

\subsection{Step-wise Weight Assessment Ratio Analysis (SWARA)}

This method is focused on criteria and not alternatives. SWARA method is presented by Keršulienè et al. (2010) for evaluating criteria with a new perspective. There are some other methods for evaluating criteria like AHP, ANP and FARE. All these methods are organized based on pairwise comparison and related to direct relations of criteria. During these years after 2010, applications of SWARA method has widened. Also the main logic of this method has developed in some researches like: (Hashemkhani
Zolfani, Saparauskas 2013) and (Hashemkhani Zolfani, Bahrami 2014) in general dimensions of method. Both previous researches believed that SWARA method is so suitable for policy making and decision making in top level. In fact each issue should be solved based on special circumstances eventually this topic should be considered. The experts are the main source of competency in SWARA methodology.

In comparison to other methods like AHP and ANP; SWARA has totally different characteristics. At the first step experts should make decision about priority of each issue. The priority should be based on needs and situation. SWARA can be deployed easily in abnormal or complicated situation. Experts are freer to make decision. At the next step experts should express their opinion about values of criteria. $S_{j}$ is a symbol for this issue and each expert should express his/her opinion as a percentage. Percentage's units in all previous researches were based on $5 \%$ intervals.

Application of this method has increased in recent years. This method was applied in different methodological applications. In some researches SWARA is deployed singly but also this method developed in some new hybrid MCDM methodologies like SWARA-VIKOR, SWARACOPRAS, SWARA-COPRAS-G and SWARA-WASPAS. All developments of decision making models based on SWARA method up to now are listed in Table 3.

Table 3. Methodological development of SWARA method

\begin{tabular}{|c|c|c|c|}
\hline & Topic & Methodology & Reference \\
\hline 1 & Design of products & SWARA & Hashemkhani Zolfani et al. (2013a) \\
\hline 2 & $\begin{array}{l}\text { Investigating on the success factors of online } \\
\text { games based on explorer }\end{array}$ & SWARA & Hashemkhani Zolfani et al. (2013b) \\
\hline 3 & $\begin{array}{l}\text { Prioritizing Sustainability Assessment Indicators } \\
\text { of Energy System }\end{array}$ & SWARA & Hashemkhani Zolfani, Saparauskas (2013) \\
\hline 4 & Supplier selection in agile environment & SWARA-VIKOR & Alimardani et al. (2013) \\
\hline 5 & $\begin{array}{l}\text { Investment prioritizing investment in high tech } \\
\text { industries }\end{array}$ & SWARA-COPRAS & Hashemkhani Zolfani, Bahrami (2014) \\
\hline 6 & $\begin{array}{l}\text { Decision making on business issues with } \\
\text { foresight perspective }\end{array}$ & SWARA-WASPAS & Hashemkhani Zolfani et al. (2013c) \\
\hline 7 & $\begin{array}{l}\text { Evaluation of real-time intelligent sensors for } \\
\text { structural health monitoring of bridges }\end{array}$ & SWARA-WASPAS & Bitarafan et al. (2014) \\
\hline 8 & $\begin{array}{l}\text { Assessment of regions priority for } \\
\text { implementation of solar plants }\end{array}$ & SWARA-WASPAS & Vafaeipour et al. (2014) \\
\hline 9 & Personnel selection & Game Theory-SWARA & $\begin{array}{l}\text { Hashemkhani Zolfani, Seyed Agha } \\
\text { Banihashemi (2014) }\end{array}$ \\
\hline 10 & External wall insulation & SWARA-TODIM & Ruzgys et al. (2014) \\
\hline 11 & Selection of a Packaging Design & SWARA & Stanujkic et al. (2015) \\
\hline 12 & Glasshouse locating & SWARA-COPRAS & Haghnazar Kouchaksaraei et al. (2015) \\
\hline 13 & $\begin{array}{l}\text { Technology Foresight About R\&D Projects } \\
\text { Selection }\end{array}$ & SWARA & Hashemkhani Zolfani et al. (2015) \\
\hline 14 & Planning the priority of high tech industries & SWARA-WASPAS & Ghorshi Nezhad et al. (2015) \\
\hline
\end{tabular}


The original procedure to the criteria weights determination using SWARA can be expressed as follows:

Step 1 - All criteria should be sorted based on expert ideas (Zavadskas, Vilutienè 2006).

Step 2 - From the second criterion, the comparative importance of the average value $s_{j}$ should be determined as follows: the relative importance of the criterion $j$ in relation to the previous $(j-1)$ criterion (Stanujkic et al. 2015).

Step 3 - Determine the coefficient $k_{j}$ :

$$
k_{j}=\left\{\begin{array}{cc}
1 & j=1 \\
s_{j}+1 & j>1
\end{array}\right.
$$

Step 4 - Determine the recalculated weight $w_{j}$ :

$$
w_{j}=\left\{\begin{array}{cc}
1 & j=1 \\
\frac{x_{j-1}}{k_{j}} & j>1 .
\end{array}\right.
$$

Step 5 - The final step in the calculation of criteria weights:

$$
q_{j}=\frac{w_{j}}{\sum_{k=1}^{n} w_{j}},
$$

where $q_{j}$ denotes the relative weight of the criterion $j$. The calculating part of SWARA method is from determination of criteria weights till the end.

\subsection{Weighted Aggregates Sum Product Assessment (WASPAS)}

WASPAS method is a new MCDM method based on Weighted Sum Model (WSM) and Weighted Product Model (WPM). Zavadskas et al. (2012) illustrated that this aggregation makes WASPAS better in comparison with WSM and WPM. WASPAS calculation is based on these steps:

\subsubsection{Normalized decision making matrix based on:}

$$
\bar{x}_{i j}=\frac{x_{i j}}{\underset{i}{o p t} x_{i j}}, \text { where } i=\overline{1, m} ; j=\overline{1, n} .
$$

If opt value is max

$$
\bar{x}_{i j}=\frac{o_{i} x_{i j}}{x_{i j}}, \text { where } i=\overline{1, m} ; j=\overline{1, n} .
$$

If opt value is $\min$.

3.2.2. Calculating WASPAS weighted and normalized decision making matrix for summarizing part:

$$
\bar{x}_{i j, s u m}=\bar{x}_{i j} q_{j} \text {, where } i=\overline{1, m} ; j=\overline{1, n} .
$$

\subsubsection{Calculating WASPAS weighted and normalized} decision making matrix for multiplication part:

$$
\bar{x}_{i j, m u l t}=\bar{x}_{i j}, \text { where } i=\overline{1, m} ; j=\overline{1, n} .
$$

\subsubsection{Final calculating for evaluating and prioritizing} alternatives based on:

$$
W P S_{i}=0.5 \sum_{j=1}^{n} \bar{x}_{i j}+0.5 \prod_{j=1}^{n} \bar{x}_{i j} \text {, where } i=\overline{1, m} ; j=\overline{1, n}
$$

All the researches based on the WASPAS method up to now are described in several references as below:

Zavadskas et al. (2012) in developing WASPAS as a new methodology; Hashemkhani Zolfani et al. (2013c) in decision making on business issues with foresight perspective; Dejus and Antucheviciene (2013) in assessment of health and safety solutions at a construction site; Šiožinytė and Antuchevicienè (2013) in solving the problems of daylighting and tradition continuity in a reconstructed vernacular building, Hashemkhani Zolfani et al. (2016a) in presenting Prospective Multiple Attribute Decision Making (PMADM) and Hashemkhani Zolfani et al. (2016b) in presenting Multiple Attribute Decision Making (MADM) based scenarios.

\section{Experts' information}

In the process of this research, eight experts were participating. They were from different field of expertise such as: Chemistry, Environmental engineering, Chemical engineering, Electrical engineering, Industrial engineering, Mechanical engineering and Civil engineering. All the general information about them is shown in Table 4.

\section{Findings}

As mentioned before, this research is organized based on two MCDM methods as a hybrid method. This section is includes two sections. The first part is results of SWARA method and the second part is related to the results of WASPAS method. These two sections are prepared based on experts' evaluation.

\subsection{SWARA's result}

In this section priority of criteria and sub-criteria is shown. All information about priority and weights of criteria and sub-criteria is illustrated in Tables 5-8. $\mathrm{S}_{\mathrm{j}}$ s are calculated based on average of experts' evaluations. Priority of all criteria is defined again based on experts' evaluation similar to SWARA's methodology.

The weightage of main criteria and their priority are shown in Table 5. Environmental criteria were the most important in general. 
Table 4. Background information of experts

\begin{tabular}{|c|c|c|c|c|c|c|c|c|}
\hline & 1 & 2 & 3 & 4 & 5 & 6 & 7 & 8 \\
\hline Gender & female & male & male & male & female & female & male & male \\
\hline $\begin{array}{l}\text { Field of } \\
\text { Study }\end{array}$ & Chemistry & $\begin{array}{l}\text { Environmental } \\
\text { engineering }\end{array}$ & $\begin{array}{l}\text { Chemical } \\
\text { engineering }\end{array}$ & Chemistry & $\begin{array}{l}\text { Electrical } \\
\text { engineering }\end{array}$ & $\begin{array}{l}\text { Industrial } \\
\text { Engineering }\end{array}$ & $\begin{array}{l}\text { Mechanical } \\
\text { engineering }\end{array}$ & $\begin{array}{l}\text { Civil } \\
\text { engineering }\end{array}$ \\
\hline $\begin{array}{l}\text { Education } \\
\text { Background }\end{array}$ & $\mathrm{PhD}$ & Master & $\mathrm{PhD}$ & $\mathrm{PhD}$ & Master & $\mathrm{PhD}$ & Bachelor & Bachelor \\
\hline $\begin{array}{l}\text { Work } \\
\text { experience }\end{array}$ & 15 & 18 & 20 & 10 & 10 & 12 & 16 & 14 \\
\hline
\end{tabular}

Table 5. Final results of SWARA method in weighting criteria

\begin{tabular}{|c|c|c|c|c|}
\hline Criterion & $\begin{array}{c}\text { The comparative } \\
\text { importance of average } \\
\text { value } s_{j}\end{array}$ & $\begin{array}{c}\text { Coefficient } \\
k_{j}=s_{j}+1\end{array}$ & $\begin{array}{l}\text { Recalculated weight } \\
\qquad w_{j}=\frac{x_{j-1}}{k_{j}}\end{array}$ & $\begin{array}{c}\text { Weight } \\
q_{j}=\frac{w_{j}}{\sum w_{j}}\end{array}$ \\
\hline $\mathrm{C}_{1}$ & & 1 & 1.0000 & 0.3305 \\
\hline $\mathrm{C}_{2}$ & 0.2188 & 1.2188 & 0.8205 & 0.2712 \\
\hline $\mathrm{C}_{3}$ & 0.2313 & 1.2313 & 0.6664 & 0.2203 \\
\hline $\mathrm{C}_{4}$ & 0.2375 & 1.2375 & 0.5385 & 0.1780 \\
\hline
\end{tabular}

Table 6. Final results of SWARA method in weighting sub-criteria of environmental

\begin{tabular}{cccccc}
\hline Criterion & $\begin{array}{c}\text { The comparative } \\
\text { importance of } \\
\text { average value } s_{j}\end{array}$ & $\begin{array}{c}\text { Coefficient } \\
k_{j}=s_{j}+1\end{array}$ & $\begin{array}{c}\text { Recalculated weight } \\
w_{j}=\frac{x_{j-1}}{k_{j}}\end{array}$ & $\begin{array}{c}\text { Weight } \\
q_{j}=\frac{w_{j}}{\sum w_{j}}\end{array}$ & Final weights \\
\hline $\mathrm{C}_{1-1}$ & 1 & 1 & 0.5416 & 0.1790 \\
\hline $\mathrm{C}_{1-2}$ & 0.1813 & 1.1813 & 0.8465 & 0.4584 & 0.1515 \\
\hline
\end{tabular}

Table 7. Final results of SWARA method in weighting sub-criteria of economic

\begin{tabular}{cccccc}
\hline Criterion & $\begin{array}{c}\text { The comparative } \\
\text { importance of } \\
\text { average value } s_{j}\end{array}$ & $\begin{array}{c}\text { Coefficient } \\
k_{j}=s_{j}+1\end{array}$ & $\begin{array}{c}\text { Recalculated weight } \\
w_{j}=\frac{x_{j-1}}{k_{j}}\end{array}$ & \multicolumn{2}{c}{$\begin{array}{c}q_{j}=\frac{w_{j}}{\sum w_{j}} \\
\text { Finhal weights }\end{array}$} \\
\hline $\mathrm{C}_{2-1}$ & 0.2313 & 1.0000 & 1.0000 & 0.4001 & 0.1085 \\
\hline $\mathrm{C}_{2-2}$ & 0.1813 & 1.2313 & 0.8121 & 0.3249 & 0.0881 \\
\hline $\mathrm{C}_{2-3}$ & 1.1813 & 0.6875 & 0.2750 & 0.0746 \\
\hline
\end{tabular}

Table 8. Final results of SWARA method in weighting sub-criteria of chemical

\begin{tabular}{cccccc}
\hline Criterion & $\begin{array}{c}\text { The comparative } \\
\text { importance of } \\
\text { average value } s_{j}\end{array}$ & $\begin{array}{c}\text { Coefficient } \\
k_{j}=s_{j}+1\end{array}$ & $\begin{array}{c}\text { Recalculated weight } \\
w_{j}=\frac{x_{j-1}}{k_{j}}\end{array}$ & $\begin{array}{c}\text { Weight } \\
q_{j}=\frac{w_{j}}{\sum w_{j}}\end{array}$ & Final weights \\
\hline $\mathrm{C}_{3-2}$ & 0.1938 & 1 & 1.0000 & 0.3167 & 0.0698 \\
\hline $\mathrm{C}_{3-3}$ & 0.1750 & 1.1938 & 0.8377 & 0.2653 & 0.0584 \\
\hline $\mathrm{C}_{3-4}$ & 0.1750 & 1.175 & 0.7129 & 0.2258 & 0.0497 \\
\hline $\mathrm{C}_{3-1}$ & 1.175 & 0.6067 & 0.1922 & 0.0423 \\
\hline
\end{tabular}


The final weightage of each sub-criteria is calculated based on its criteria. Results of SWARA method are applied in next step.

\subsection{WASPAS's results}

Evaluating of four different alternatives is organized in this section based on WASPAS methodology. All alternatives evaluated based on criteria and sub-criteria. All the procedures of this methodology are shown in Tables 9-13.

Different sort of AOPs were ranked base on SWARAWASPAS results. Five potential advance oxidation processes in this paper have been introduced as alternatives for wastewater purification plant. Priority of alternatives is shown in Table 13 based on calculating formula 4 and

Table 9. Decision making matrix

\begin{tabular}{lcccccccccc}
\hline & \multicolumn{2}{c}{$\mathrm{C}_{1}$} & \multicolumn{2}{c}{$\mathrm{C}_{2}$} & & & $\mathrm{C}_{3}$ & $\mathrm{C}_{4}$ \\
\hline & $\mathrm{C}_{1-1}$ & $\mathrm{C}_{1-2}$ & $\mathrm{C}_{2-1}$ & $\mathrm{C}_{2-2}$ & $\mathrm{C}_{2-3}$ & $\mathrm{C}_{3-1}$ & $\mathrm{C}_{3-2}$ & $\mathrm{C}_{3-3}$ & $\mathrm{C}_{3-4}$ & $\mathrm{C}_{4}$ \\
\hline Weight & 0.1790 & 0.1515 & 0.1085 & 0.0881 & 0.0746 & 0.0423 & 0.0698 & 0.0584 & 0.0497 & 0.1780 \\
\hline & $\mathrm{Max}$ & $\mathrm{Max}$ & $\mathrm{Min}$ & $\mathrm{Min}$ & $\mathrm{Min}$ & $7(\mathrm{Opt})$ & $\mathrm{Min}$ & $\mathrm{Min}$ & $\mathrm{Max}$ & $\mathrm{Max}$ \\
\hline Ozonation & 52.85 & 1.40 & 88639 & 546.59 & 2070 & 7 & 82.93 & 54.41 & $1.23 \times 10^{-3}$ & 2010 \\
\hline Fenton & 64.25 & 17.20 & 8568.50 & 6.20 & 1 & 2.9 & 50 & 1017.21 & $5.2 \times 10^{-4}$ & 2011 \\
\hline $\begin{array}{l}\text { Electrochemical } \\
\text { Oxidation }\end{array}$ & 88.90 & 1.05 & 50210 & 12.19 & 219.28 & 7.40 & 150 & 5025 & $4.79 \times 10^{-3}$ & 2010 \\
\hline $\begin{array}{l}\text { UV/ Photo- } \\
\text { catalysis }\end{array}$ & 85 & 12.3 & 70400 & 27.30 & 31.75 & 7.40 & 153.75 & 434 & $2.87 \times 10^{-3}$ & 2010 \\
\hline $\begin{array}{l}\text { UV/H } \\
2\end{array}$ & 87.50 & 5.10 & 10800 & 50.50 & 5.4 & 6.30 & 33.75 & 696 & $5.67 \times 10^{-5}$ & 2009 \\
\hline
\end{tabular}

* All the criteria are real data. Also there is an exception and that is $\mathrm{C}_{3-1}$. The optimum rate for this criterion is 7 and max or min isn't suitable for this criteria.

Table 10. WASPAS normalized decision making matrix

\begin{tabular}{lccccccccccc}
\hline & \multicolumn{2}{c}{$\mathrm{C}_{1}$} & \multicolumn{2}{c}{$\mathrm{C}_{2}$} & & & $\mathrm{C}_{3}$ & & $\mathrm{C}_{4}$ \\
\hline & $\mathrm{C}_{1-1}$ & $\mathrm{C}_{1-2}$ & $\mathrm{C}_{2-1}$ & $\mathrm{C}_{2-2}$ & $\mathrm{C}_{2-3}$ & $\mathrm{C}_{3-1}$ & $\mathrm{C}_{3-2}$ & $\mathrm{C}_{3-3}$ & $\mathrm{C}_{3-4}$ & $\mathrm{C}_{4}$ \\
\hline Weight & 0.1790 & 0.1515 & 0.1085 & 0.0881 & 0.0746 & 0.0423 & 0.0698 & 0.0584 & 0.0497 & 0.1780 \\
\hline Max & $\mathrm{Max}$ & $\mathrm{Min}$ & $\mathrm{Min}$ & $\mathrm{Min}$ & $7(\mathrm{Opt})$ & $\mathrm{Min}$ & $\mathrm{Min}$ & $\mathrm{Max}$ & $\mathrm{Max}$ \\
\hline Ozonation & 0.5945 & 0.0814 & 0.0967 & 0.0113 & 0.0005 & 1.0000 & 0.4070 & 1.0000 & 0.2568 & 0.9995 \\
\hline Fenton & 0.7227 & 1.0000 & 1.0000 & 1.0000 & 1.0000 & 2.4138 & 0.6750 & 0.0535 & 0.1086 & 1.0000 \\
\hline $\begin{array}{l}\text { Electrochemical } \\
\text { Oxidation }\end{array}$ & 1.0000 & 0.0610 & 0.1707 & 0.5086 & 0.0046 & 0.9459 & 0.2250 & 0.0108 & 1.0000 & 0.9995 \\
\hline $\begin{array}{l}\text { UV/ } \\
\text { Photocatalysis }\end{array}$ & 0.9561 & 0.7151 & 0.1217 & 0.2271 & 0.0315 & 0.9459 & 0.2195 & 0.1254 & 0.5992 & 0.9995 \\
\hline $\begin{array}{l}\text { UV/H } \\
2\end{array}$ & 0.9843 & 0.2965 & 0.7934 & 0.1228 & 0.1852 & 1.1111 & 1.0000 & 0.0782 & 0.0118 & 0.9990 \\
\hline
\end{tabular}

This table is calculated based on formula 1 .

Table 11. WASPAS weighted and normalized decision making matrix for summarizing part

\begin{tabular}{lccccccccccc}
\hline & \multicolumn{2}{c}{$\mathrm{C}_{1}$} & \multicolumn{2}{c}{$\mathrm{C}_{2}$} & & & $\mathrm{C}_{3}$ & & $\mathrm{C}_{4}$ \\
\hline & $\mathrm{C}_{1-1}$ & $\mathrm{C}_{1-2}$ & $\mathrm{C}_{2-1}$ & $\mathrm{C}_{2-2}$ & $\mathrm{C}_{2-3}$ & $\mathrm{C}_{3-1}$ & $\mathrm{C}_{3-2}$ & $\mathrm{C}_{3-3}$ & $\mathrm{C}_{3-4}$ & $\mathrm{C}_{4}$ \\
\hline Ozonation & 0.1064 & 0.0123 & 0.0105 & 0.0010 & 0.0000 & 0.0423 & 0.0284 & 0.0584 & 0.0128 & 0.1779 \\
\hline Fenton & 0.1294 & 0.1515 & 0.1085 & 0.0881 & 0.0746 & 0.1021 & 0.0471 & 0.0031 & 0.0054 & 0.1780 \\
\hline $\begin{array}{l}\text { Electrochemical } \\
\text { Oxidation }\end{array}$ & 0.1790 & 0.0092 & 0.0185 & 0.0448 & 0.0003 & 0.0400 & 0.0157 & 0.0006 & 0.0497 & 0.1779 \\
\hline $\begin{array}{l}\text { UV/ } \\
\text { Photocatalysis }\end{array}$ & 0.1711 & 0.1083 & 0.0132 & 0.0200 & 0.0023 & 0.0400 & 0.0153 & 0.0073 & 0.0298 & 0.1779 \\
\hline UV/ $\mathrm{H}_{2} \mathrm{O}_{2}$ & 0.1762 & 0.0449 & 0.0861 & 0.0108 & 0.0138 & 0.0470 & 0.0698 & 0.0046 & 0.0006 & 0.1778 \\
\hline
\end{tabular}

This table is calculated based on formula 2 . 
Table 12. WASPAS weighted and normalized decision making matrix for multiplication part

\begin{tabular}{|c|c|c|c|c|c|c|c|c|c|c|}
\hline & \multicolumn{2}{|c|}{$\mathrm{C}_{1}$} & \multicolumn{3}{|c|}{$\mathrm{C}_{2}$} & \multicolumn{4}{|c|}{$\mathrm{C}_{3}$} & \multirow{2}{*}{$\begin{array}{l}\mathrm{C}_{4} \\
\mathrm{C}_{4} \\
\end{array}$} \\
\hline & $\mathrm{C}_{1-1}$ & $\mathrm{C}_{1-2}$ & $\mathrm{C}_{2-1}$ & $\mathrm{C}_{2-2}$ & $\mathrm{C}_{2-3}$ & $\mathrm{C}_{3-1}$ & $\mathrm{C}_{3-2}$ & $\mathrm{C}_{3-3}$ & $\mathrm{C}_{3-4}$ & \\
\hline Ozonation & 0.9111 & 0.6838 & 0.7761 & 0.6739 & 0.5658 & 1.0000 & 0.9392 & 1.0000 & 0.9347 & 0.9999 \\
\hline Fenton & 0.9435 & 1.0000 & 1.0000 & 1.0000 & 1.0000 & 1.0380 & 0.9729 & 0.8428 & 0.8955 & 1.0000 \\
\hline $\begin{array}{l}\text { Electrochemical } \\
\text { Oxidation }\end{array}$ & 1.0000 & 0.6547 & 0.8254 & 0.9422 & 0.6689 & 0.9977 & 0.9011 & 0.7677 & 1.0000 & 0.9999 \\
\hline $\begin{array}{l}\text { UV/ Photo- } \\
\text { catalysis }\end{array}$ & 0.9920 & 0.9505 & 0.7957 & 0.8776 & 0.7726 & 0.9977 & 0.8996 & 0.8858 & 0.9749 & 0.9999 \\
\hline $\mathrm{UV} / \mathrm{H}_{2} \mathrm{O}_{2}$ & 0.9972 & 0.8318 & 0.9752 & 0.8313 & 0.8818 & 1.0045 & 1.0000 & 0.8617 & 0.8021 & 0.9998 \\
\hline
\end{tabular}

This table is calculated based on formula 3.

Table 13. The results of WASPAS

\begin{tabular}{|c|c|c|c|c|}
\hline & $0.5 \sum_{j=1}^{n} \overline{\bar{X}} i j, s u m$ & $0.5 \prod_{j=1}^{n} \overline{\bar{X}} i j, m u l t$ & $W S P_{i}$ & Ranking \\
\hline Ozonation & 0.2250 & 0.0809 & 0.3059 & 5 \\
\hline Fenton & 0.4439 & 0.3596 & 0.8035 & 1 \\
\hline Electrochemical Oxidation & 0.2679 & 0.1175 & 0.3855 & 4 \\
\hline UV/ Photocatalysis & 0.2927 & 0.1971 & 0.4898 & 3 \\
\hline $\mathrm{UV} / \mathrm{H}_{2} \mathrm{O}_{2}$ & 0.3158 & 0.2058 & 0.5216 & 2 \\
\hline
\end{tabular}

in final column shows ranking. After creating decision matrix and other steps for receiving the final ranking, according to Table 13 which shows the ultimate results of WASPAS methodology, Alternative 2 (Fenton) is the best reagent for a chemical treated section in industrial wastewater plant.

\section{Conclusions}

In the current era many techniques are proposed to treat industrial wastewater especially chemical treatment which has been developed to help the wastewater treatment systems. Selecting an appropriate chemical treatment method which can rely on less expenses and more environmental impacts can be interesting for decision makers in managing water pollution crises. Since Advance Oxidation Processes system (AOPs) is one of the leading chemical treatments method in degradation and mineralization of pollutants, this research has been accomplished based on it. This research followed five important sorts of AOPs: Ozonation, Fenton, electrochemical Oxidation, UV/Photo-catalysis, and $\mathrm{UV} / \mathrm{H}_{2} \mathrm{O}_{2}$ which are compared by MCDM methods. SWARA is applied for evaluating and weighting the criteria and WASPAS method is deployed for evaluating distinctive alternatives of the AOPs.

Different case studies have been chosen to check the applicability of influential factors such as ability of each method to mineralize the pollution, capital and operating costs, $\mathrm{pH}$ level as a significant factor of industry outlet and the amount of chemicals that are used in each technology. Eight experts from distinct scientific fields participated in this research and integrated SWARA-WASPAS decision model showed that the Fenton process is the best option in AOPs area for removing many hazardous and organic pollutants regarding environmental, economical and chemical factors. The results of this investigation can be used for decision making in real cases of future researches. Also, governments can use this methodology for basic wastewater treatment process.

\section{References}

Alimardani, M.; Hashemkhani Zolfani, S.; Aghdaie, M.; Tamosaitiene, J. 2013. A novel hybrid SWARA and VIKOR methodology for Supplier selection in an agile environment, Technological and Economic Development of Economy 19(3): 533-548. https://doi.org/10.3846/20294913.2013.814606

Autin, O.; Hartb, J.; Jarvis, P.; MacAdam, J.; Parsonsa, S.; Jefferson, B. 2013. Comparison of $\mathrm{UV} / \mathrm{TiO}_{2}$ and $\mathrm{UV} / \mathrm{H}_{2} \mathrm{O}_{2}$ processes in an annular photoreactor for removal of micropollutants: influence of water parameters on metaldehyde removal, quantum yields and energy consumption, Applied Catalysis B: Environmental 138-139: 268-275. https://doi.org/10.1016/j.apcatb.2013.02.045

Bitarafan, M.; Hashemkhani Zolfani, S.; Lale Arefi, S.; Zavadskas, E. K.; Mahmoudzadeh, A. 2014. Evaluation of real-time intelligent sensors for structural health monitoring of bridges based on SWARA-WASPAS; A case in Iran, Baltic Journal of Road and Bridge Engineering 9(4): 333-340.

https://doi.org/10.3846/bjrbe.2014.40 
Cabral da Silva, A. J.; Santos, E. V.; Carla de Oliveira Morais, C.; Martinez-Huitle, C. A.; Leal Castro, S. S. 2013. Electrochemical treatment of fresh, brine and saline produced water generated by petrochemical industry using $\mathrm{Ti} / \mathrm{IrO} 2-\mathrm{Ta} 2 \mathrm{O} 5$ and BDD in flow reactor, Chemical Engineering 233: 47-55. https://doi.org/10.1016/j.cej.2013.08.023

Canizares, P.; Hernandez-Ortegab, M.; Rodrigoa, M. A.; BarreraDiazb, C. E.; Roa-Morales, G.; Saeza, C. 2009b. A comparison between Conductive-Diamond Electrochemical Oxidation and other Advanced Oxidation Processes for the treatment of synthetic melanoidins, Hazardous Materials 164: 120-125. https://doi.org/10.1016/j.jhazmat.2008.07.134

Canizares, P.; Paz, R.; Saez, C.; Rodrigo, M. 2009a. Costs of the electrochemical oxidation of wastewaters: a comparison with ozonation and Fenton oxidation processes, Environmental Management 90: 410-420.

https://doi.org/10.1016/j.jenvman.2007.10.010

Carra, I.; Ortega-Gómez, E.; Santos-Juanes, L.; Casas López, J. L.; Sánchez Pérez, J. A. 2013. Cost analysis of different hydrogen peroxide supply strategies in the solar photo-Fenton process, Chemical Engineering 224: 75-81.

https://doi.org/10.1016/j.cej.2012.09.067

Chang, E. E.; Hsing, H. J.; Chiang, P. C.; Chenc, M. Y.; Shyng, J. Y. 2008. The chemical and biological characteristics of cokeoven wastewater by ozonation, Hazardous Materials 156: 560-567. https://doi.org/10.1016/j.jhazmat.2007.12.106

Chen, Y.; Lo, S.; Kuo, J. 2011. Effects of titanate nanotubes synthesized by a microwave hydrothermal method on photocatalytic decomposition of perfluorooctanoic acid, Water Research 45: 4131-4140. https://doi.org/10.1016/j.watres.2011.05.020

Dejus, T.; Antucheviciene, J. 2013. Assessment of health and safety solutions at a construction site, Journal of Civil Engineering and Management 19(5): 728-737.

https://doi.org/10.3846/13923730.2013.812578

Esplugas, S.; Gimenez, J.; Contreras, S.; Pascual, E.; Rodriguez, M. 2002. Comparison of different advanced oxidation processes for phenol degradation, Water Research 36(4): 1034-1042. https://doi.org/10.1016/S0043-1354(01)00301-3

Ghorshi Nezhad, M. R.; Hashemkhani Zolfani, S.; Moztarzadeh, F.; Zavadskas, E. K.; Bahrami, M. 2015. Planning the priority of high tech industries based on SWARA-WASPAS methodology: the case of the nanotechnology industry in Iran, Economic Research-Ekonomska Istraživanja 28(1): 1111-1137. https://doi.org/10.1080/1331677X.2015.1102404

Gómez-Pacheco, C. V.; Sánchez-Polo, M.; Rivera-Utrilla, J.; López-Penalver, J. 2011. Tetracycline removal from waters by integrated technologies based on ozonation and biodegradation, Chemical Engineering 178: 115-121. https://doi.org/10.1016/j.cej.2011.10.023

Haghnazar Kouchaksaraei, R.; Hashemkhani Zolfani, S.; Golabchi, M. 2015. Glasshouse locating based on SWARA-COPRAS approach, International Journal of Strategic Property Management 19(2): 111-122.

https://doi.org/10.3846/1648715X.2015.1004565

Hashemkhani Zolfani, S.; Aghdaie, M. H.; Derakhti, A.; Zavadskas, E. K.; Morshed Varzandeh, M. H. 2013c. Decision making on business issues with foresight perspective; an application of new hybrid MCDM model in shopping mall locating, Expert Systems with Applications 40: 7111-7121. https://doi.org/10.1016/j.eswa.2013.06.040
Hashemkhani Zolfani, S.; Bahrami, M. 2014. Investment prioritizing in high tech industries based on SWARA-COPRAS approach, Technological and Economic Development of Economy 20(3): 534-553.

https://doi.org/10.3846/20294913.2014.881435

Hashemkhani Zolfani, S.; Farrokhzad, M.; Turskis, Z. 2013b. Investigating on successful factors of online games based on explorer, E \& M: Ekonomie a Management 16(2): 161-169.

Hashemkhani Zolfani, S.; Maknoon, R.; Zavadskas, E. K. 2016a. An introduction to Prospective Multiple Attributes Decision Making (PMADM), Technological and Economic Development of Economy 22(2): 309-326. https://doi.org/10.3846/20294913.2016.1150363

Hashemkhani Zolfani, S.; Maknoon, R.; Zavadskas, E. K. 2016b. Multiple Attribute Decision Making (MADM) based scenarios, International Journal of Strategic Property Management 20(1): 101-111. https://doi.org/10.3846/1648715X.2015.1132487

Hashemkhani Zolfani, S.; Salimi, J.; Maknoon, R.; Kildiene, S. 2015. Technology foresight about R\&D projects selection; Application of SWARA method at the policy making level, Inzinerine Ekonomika-Engineering Economics 26(5): 571-580. https://doi.org/10.5755/j01.ee.26.5.9571

Hashemkhani Zolfani, S.; Saparauskas, J. 2013. New Application of SWARA method in prioritizing sustainability assessment indicators of energy system, Inzinerine Ekonomika-Engineering Economics 24(5): 408-414.

Hashemkhani Zolfani, S.; Seyed Agha Banihashemi, S. 2014. Personnel selection based on a novel model of game theory and MCDM approaches, in $8^{\text {th }}$ International Scientific Conference "Business and Management 2014", 191-198.

Hashemkhani Zolfani, S.; Zavadskas, E. K.; Turskis, Z. 2013a. Design of products with both International and Local perspectives based on Yin-Yang balance theory and SWARA method, Economic Research-Ekonomska Istraživanja 26(2): 153-166. https://doi.org/10.1080/1331677X.2013.11517613

Keršulienė, V.; Zavadskas, E. K.; Turskis, Z. 2010. Selection of rational dispute resolution method by applying new step-wise weight assessment ratio analysis (SWARA), Journal of Business Economics and Management 11(2): 243-258. https://doi.org/10.3846/jbem.2010.12

Khan, D.; Samadder, S. R. 2015. A simplified multi-criteria evaluation model for landfill site ranking and selection based on AHP and GIS, Journal of Environmental Engineering and Landscape Management 23(4): 267-278.

https://doi.org/10.3846/16486897.2015.1056741

Kim, Tae-Hun.; Kim, S. D.; Kim, H. Y.; Lim, S. J.; Lee, M.; Yu, S. 2012. Degradation and toxicity assessment of sulfamethoxazole and chlortetracycline using electron beam, ozone and UV, Hazardous Materials 227-228: 237-242. https://doi.org/10.1016/j.jhazmat.2012.05.038

Krichevskaya, M.; Klauson, D.; Portjanskaja, E.; Preis, S. 2011. The Cost Evaluation of advanced Oxidation Processes in Laboratory and Pilot-Scale Experiments, International Ozone Association 33: 211-223. https://doi.org/10.1080/01919512.2011.554141

Kucas, A. 2010. Location prioritization by means of multicriteria spatial decision-support systems: a case study of forest fragmentation-based ranking of forest administrative areas, Journal of Environmental Engineering and Landscape Management 18(4): 312-320. https://doi.org/10.3846/jeelm.2010.36 
Leyva-Díaz, J. C.; López-López, C.; Martín-Pascual, J.; Muñío, M. M.; Poyatos, J. M. 2015. Kinetic study of the combined processes of a membrane bioreactor and a hybrid moving bed biofilm reactor-membrane bioreactor with advanced oxidation processes as a post-treatment stage for wastewater treatment, Chemical Engineering and Processing 91: 57-66. https://doi.org/10.1016/j.cep.2015.03.017

Liu, P.; He, L.; Yu, X. 2016. Generalized hybrid aggregation operators based on the 2-dimension uncertain linguistic information for multiple attribute group decision making, Group Decision and Negotiation 25(1): 103-126. https://doi.org/10.1007/s10726-015-9434-x

Liu, P.; Jin, F. 2012. A multi-attribute group decision-making method based on weighted geometric aggregation operators of interval-valued trapezoidal fuzzy numbers, Applied Mathematical Modelling 36(6): 2498-2509.

https://doi.org/10.1016/j.apm.2011.09.006

Liu, P.; Jin, F., Zhang, X.; Su, Y.; Wang, M. 2011. Research on the multi-attribute decision-making under risk with interval probability based on prospect theory and the uncertain linguistic variables, Knowledge-Based Systems 24(4): 554-561. https://doi.org/10.1016/j.knosys.2011.01.010

Liu, P.; Shi, L. 2015. The generalized hybrid weighted average operator based on interval neutrosophic hesitant set and its application to multiple attribute decision making, Neural Computing and Applications 26(2): 457-471. https://doi.org/10.1007/s00521-014-1736-4

Liu, P.; Zhang, X.; Jin, F. 2012. A multi-attribute group decisionmaking method based on interval-valued trapezoidal fuzzy numbers hybrid harmonic averaging operators, Journal of Intelligent \& Fuzzy Systems 23(5): 159-168.

Lizama, C.; Freer, J.; Baeza, J.; Mansilla, H. 2002. Optimized photodegradation of Reactive Blue 19 on $\mathrm{TiO}_{2}$ and $\mathrm{ZnO}$ suspensions, Catalysis Today 76: 235-246. https://doi.org/10.1016/S0920-5861(02)00222-5

Mantzavinos, D.; Psillakis, E. 2004. Review Enhancement of biodegradability of industrial wastewaters by chemical oxidation pre-treatment, Journal of Chemical Technology and Biotechnology 79: 431-454. https://doi.org/10.1002/jctb.1020

Oppenländer, T. 2003. Photochemical purification of water and air, WILEY-VCH.

Prieto-Rodriguez, L.; Oller, I.; Klamerth, N.; Aguera, A.; Rodriguez, E. M.; Malato S. 2013. Application of solar AOP and ozonation for elimination of micropollutants in municipal wastewater treatment plant effluents, Water research 47: 1521-1528. https://doi.org/10.1016/j.watres.2012.11.002

Ruzgys, A.; Volvačiovas, R.; Ignatavičius, Č.; Turskis, Z. 2014. Integrated evaluation of external wall insulation in residential buildings using SWARA-TODIM MCDM method, Journal of Civil Engineering and Management 20(1): 103-110. https://doi.org/10.3846/13923730.2013.843585

Saeed, T.; Sun, G. 2012. A review on nitrogen and organics removal mechanisms in subsurface flow constructed wetlands: dependency on environmental parameters, operating conditions and supporting media, Environmental Management 112: 429-448.

https://doi.org/10.1016/j.jenvman.2012.08.011

Sharma, V. K.; Triantis, T. M.; Antoniou, M. G.; He, X.; Pelaez, M.; Han, C.; Song, W.; O’Shea, K. E.; de la Cruz, A. A.; Kaloudis, T.; Hiskia, A.; Dionysiou, D. D. 2012. Destruction of microcystins by conventional and advanced oxidation processes: a review, Separation and Purification Technology 91: 3-17. https://doi.org/10.1016/j.seppur.2012.02.018

Sievers, M. 2011. Advanced oxidation processes. Earth Systems and Environmental Sciences, Treatise on Water Science 4: 377-408. https://doi.org/10.1016/B978-0-444-53199-5.00093-2

Šiožinyte, E.; Antuchevičienė, J. 2013. Solving the problems of daylighting and tradition continuity in a reconstructed vernacular building, Journal of Civil Engineering and Management 19(6): 873-882. https://doi.org/10.3846/13923730.2013.851113

Stanujkic, D.; Karabasevic, D.; Zavadskas, E. K. 2015. A Framework for the Selection of a Packaging Design Based on the SWARA Method, Inzinerine Ekonomika - Engineering Economics 26(2): 181-187.

Teh, C. M.; Mohamed, A. R. 2011. Roles of titanium dioxide and ion-doped titanium dioxide on photocatalytic degradation of organic pollutants (phenolic compounds and dyes) in aqueous solutions: a review, Journal of Alloys and Compounds 509(5): 1648-1660.

https://doi.org/10.1016/j.jallcom.2010.10.181

Tizaoui, C.; Mezughi, K.; Bickley, R. 2011. Heterogeneous photocatalytic removal of the herbicide clopyralid and its comparison with $\mathrm{UV} / \mathrm{H}_{2} \mathrm{O}_{2}$ and ozone oxidation techniques, $D e$ salination 273: 197-204. https://doi.org/10.1016/j.desal.2010.11.036

Turskis, Z.; Lazauskas, M.; Zavadskas, E. K. 2012. Fuzzy multiple criteria assessment of construction site alternatives for nonhazardous waste incineration plant in Vilnius City, Applying ARAS-F and AHP Methods, Journal of Environmental Engineering and Landscape Management 20(2): 111-120. https://doi.org/10.3846/16486897.2011.645827

Vafaeipour, M.; Hashemkhani Zolfani, S.; Morshed Varzandeh, M. H.; Derakhti, A.; Keshavarz Eshkalag, M. 2014. Assessment of regions priority for implementation of solar plants in Iran: new application of a hybrid multi-criteria decision making approach, Energy Conversion and Management 86: 653-663. https://doi.org/10.1016/j.enconman.2014.05.083

Zavadskas, E. K.; Turskis, Z.; Antucheviciene, J.; Zakarevicius, A. 2012. Optimization of weighted aggregated sum product assessment, Elektronika ir Elektrotechnika 122(6): 3-6. https://doi.org/10.5755/j01.eee.122.6.1810

Zavadskas, E. K.; Vilutiene, T. 2006. A multiple criteria evaluation of multi-family apartment block's maintenance contracts: I-Model for maintenance of contractor evaluation and determination of its selection criteria, Building and Environment 41: 621-632. https://doi.org/10.1016/j.buildenv.2005.02.019

Mohamad Reza KHODADADI received his B.S degree in Chemical Engineering in 2012 and a Master degree in Nanochemistry in 2014. He is currently pursuing a PhD in Faculty of chemistry, Picardie Jules Verne University, Amiens, France. Mohamad background and focus on chemistry and Nano technology has led him to tackle the various challenges in engineering, environment and sustainability. 
Sarfaraz HASHEMKHANI ZOLFANI is PhD candidate of Technology Foresight in Amirkabir University of Technology (Tehran Polytechnic). He is in cooperating with Futures Studies Research Institute of Amirkabir University of Technology (Tehran Polytechnic) and Sustainability office of Amirkabir University of Technology (Tehran Polytechnic). He is part time research associate in council for futures studies, Iranian Academy of Sciences and adviser to the president, Iranian Society of Future Studies. He is Council member of International Association of Grey System and Uncertain Analysis (GSUA) and member of EURO Working Group OR in Sustainable Development and Civil Engineering. He is reviewer in journals like: Technological and Economic Development of Economy, Technological Forecasting and Social Change, Evaluation and Program Planning, Journal of Business Economics and Management, International Journal of Strategic Property Management, and etc. He is author of more than 50 scientific papers that presented, published or reviewed at/for International Conferences and Journals (including ISI-cited publications). He has published in journals such as: Expert Systems with Applications, Energy Conversion and Management, Journal of Cleaner Production, Technological and Economic Development of Economy, Journal of Business Economics and Management, International Journal of Strategic Property Management, Archives of Civil and Mechanical Engineering, and etc. His research interests include: Performance Evaluation, Strategic Management, Decisionmaking Theory, Supply Chain Management, (Dynamic/Prospective) Multi Criteria Decision Making, Futures Studies, Sustainable Development and Game Theory.

Morteza YAZDANI is a PhD Scholar in Business Economic at Universidad Europea de Madrid, Spain. His main research interests are application of multi criteria decision making in different fields as material science, supply chain management, construction management and also strategic planning. He is member of editorial board at International Journal of Business and Systems research (INDERSCIENCE) and reviewer of journal "Sustainability". He has published in top international journals such as Journal of Civil Engineering and Management, Technological and Economic Development of Economy, Expert Systems with Applications, Materials and Design and International Journal of Logistics Research and applications.

Edmundas Kazimieras ZAVADSKAS. PhD, DSc, h.c.multi. Prof., the Head of the Department of Construction Technology and Management at Vilnius Gediminas Technical University, Lithuania. Senior Research Fellow at the Research Institute of Smart Building Technologies. PhD in Building Structures (1973). DrSc in Building Technology and Management (1987). A member of Lithuanian and several foreign Academies of Sciences. Doctore Honoris Causa from Poznan, Saint Petersburg and Kiev universities. Honorary International Chair Professor of the National Taipei University of Technology. A member of international organizations; a member of steering and programme committees at many international conferences; a member of the editorial boards of several research journals; the author and co-author of more than 400 papers and a number of monographs in Lithuanian, English, German and Russian. The editor-in-chief of journals Technological and Economic Development of Economy and Journal of Civil Engineering and Management. Research interests: building technology and management, decision-making theory, automation in design and decision support systems. 